\title{
Analysis of Independence Level and Financial Performance of Post-Expansion Regions
}

\author{
Boni Saputra ${ }^{1}$, Hidayatul Fajri ${ }^{2}$, Pratiwi Nurhabibi ${ }^{3}$ \\ \{bonisaputra@fis.unp.ac.id ${ }^{1}$, hidayatulfajri@fis.unp.ac.id ${ }^{2}$, pratiwi@ fis.unp.ac.id $\left.{ }^{3}\right\}$ \\ Department of Public Administration, Universitas Negeri Padang, Padang, Indonesia ${ }^{1,2,3}$
}

\begin{abstract}
The focus and purpose of this study are to analyze and determine the level of independence and regional financial performance after the division in several regions in West Sumatra Province. The research method used a quantitative descriptive approach. The research sample used a purposive sampling technique. The research was conducted in three Regency after the division of West Sumatra Province, Dharmasraya, South Solok, and West Pasaman Regency. Data collection techniques through observation, interviews, literature study, and documentation study. The data used are secondary, namely the Regency budget realization report (LRA) after the division of the 2014-2018 period counting the last five years. The results of the study found that post-division regional financial performance is still low, while the level of regional financial independence is still low or shows a pattern of consultative relationships. The percentage level of regional financial independence is certainly not the same and is different for each region. This research implies that local governments must be able to increase regional financial independence (through identification and utilization of potential regional assets owned) and reduce the level of dependence on the central and provincial governments.
\end{abstract}

Keywords: Regional Financial Independence; Regional Financial Performance; Regional Original Income (PAD)

\section{Introduction}

In the context of implementing regional autonomy and fiscal decentralization, local governments are required to have greater regional financial independence. So, with this scheme, it is hoped that regions can minimize the level of dependence on central and provincial government assistance through the balance fund. Sharing the problems that accompany fiscal decentralization makes the regions more dependent on the central government. Currently, fiscal decentralization from the central government has given authority freely to regional governments to be creative in exploring financial sources in the regional administrative area, both in the form of regional taxes, regional levies, the results of separated regional wealth management, and other local revenue (PAD). In line with this, opinion [1] states that autonomous regions must have the authority and ability to take their financial resources, and depend on the government to the center to a minimum, so that PAD must be the largest source of finance to finance regional administration.

The success of regional autonomy cannot be separated from the performance of regional governments in managing their finances in an orderly manner, obeying laws and regulations, 
efficient, economical, effective, transparent, and accountable. Regional financial management is carried out in an integrated system as outlined in the regional budget (APBD) which is determined annually by regional regulations. The regional financial performance or regional capacity is one measure that can be used to see the region's ability to carry out regional autonomy. [2] argues that the form or output of regional financial performance appraisal is in the form of financial ratios formed from the elements of the regional head's accountability report in the form of APBD calculations. Through the Budget Realization report published by the local government, it can provide very useful information for assessing regional financial performance.

To ensure the realization of regional autonomy, especially in the field of regional finance, which is getting better, the government has also issued regulations in the form of Law No.33 of 2004 concerning the financial balance between the center and regions, Government Regulation Number 58 of 2005 concerning guidelines for regional financial management and strengthened with the Permendagri Number 13 of 2006 concerning guidelines for regional financial management. With the existence of an independent regional financial management regulation, there are demands for local governments to make financial reports and budget management transparently to the public. This is what underlies the need to implement the value of money in local governments. The existence of this Presidential Regulation [3],[4] has also significantly brought about fundamental changes in various aspects of regional governance, particularly in the area of regional finance.

In increasing self-reliance, efforts are needed to improve their financial capacity, namely by increasing PAD through innovation, by increasing the acceptance of existing PAD sources, and by multiplying new PAD sources according to applicable regulations by taking into account the conditions and economic potential of the community. Because of the higher level of regional independence, the regions can provide higher quality public services.

The financial capacity of a region can be seen from the amount of Regional Original Revenue (PAD) that the region receives. Related to the granting of greater regional autonomy to regions. PAD is always seen as an indicator or criterion for measuring the dependence of a region on its center. In principle, the greater the PAD contribution to the APBD, the smaller the regional dependence on the center as a consequence of the implementation of regional autonomy with real and responsible principles.

When viewed from the existing data, almost all regions in Indonesia experience obstacles related to the level of regional financial independence. this can be seen from the following data: 

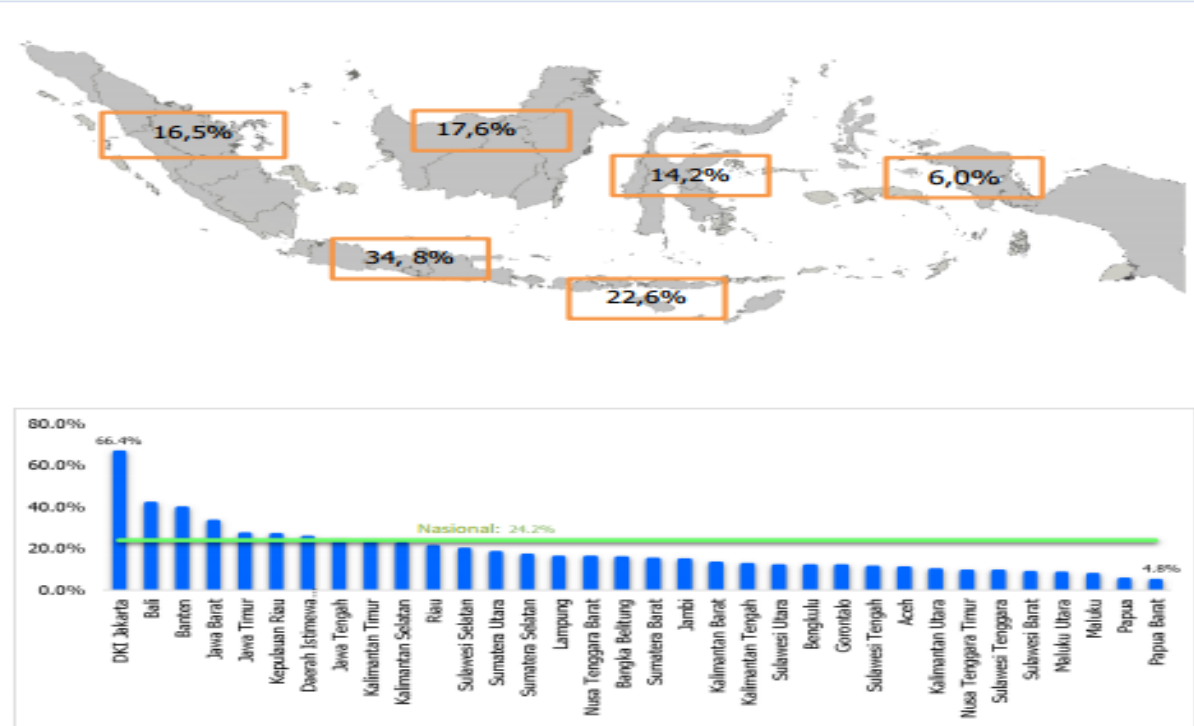

Fig.1. The ratio of Regional Independence in Indonesia (Source: Directorate General of Fiscal Balance, Ministry of Finance, 2019)

The ratio of regional independence describes the level of independence of a region to external assistance, both from the central government and other local governments. This ratio is indicated by the ratio of PAD to total regional revenue. The greater the PAD ratio, the higher the autonomy of the area. Conversely, the smaller the PAD ratio, the lower the independence of the area. The ratio of national regional independence is 24.2 percent. Regions that have a regional self-reliance ratio above the national self-reliance ratio are Java with a percentage of 34.8 percent, while the rest is below the national ratio, with Papua having the smallest ratio of 6.0 percent.

Increasing people's welfare is currently the main goal of development at the national and regional levels. Each region is given the authority to manage the potential of the region together with the community. So that local governments can develop and utilize the potential of their wealth as much as possible. To maximize the authority of regional autonomy policies, local governments must strive to increase the potential of the regions they have through Regional Original Revenue. Further, [5] explained that the higher the contribution of a region's PAD to total revenue, the greater the regional discretion to use PAD by the aspirations and needs of the community as well as for regional development priorities. This condition is also possible to be implemented by post-division regions in West Sumatra Province, such as Dharmasraya, South Solok, and West Pasaman Regency to explore regional potentials so that regions can be more independent through Regional Original Income.

Fiscal decentralization and regional autonomy, especially in terms of financial independence in many regions, especially in Indonesia, have not been implemented optimally. The results of research conducted by [6] stated that what happened was the opposite, namely that the regions were increasingly dependent on the central government. The high level of regional financial dependence on balancing funds through the central government has also occurred in several regions in West Sumatra Province, particularly in post-division regions, namely Dharmasraya, South Solok, and West Pasaman Regency. In 2018, for example, Dhamasraya Regency was ranked $12^{\text {th }}$ with PAD only Rp. 80,085,859.65., - while for South Solok Regency it is in the last 
position, namely the $19^{\text {th }}$ rank with a total PAD of Rp. 23,848,000., -, while for West Pasaman regency is in number 8 with PAD 102,623,195.68., -. With a note that the Regency government balancing funds. West Pasaman is quite high, which is ranked $12^{\text {th }}$ from other Regency (Source: West Sumatra in numbers, 2018).

The data above can certainly be assumed that the financial performance of the Dhamasraya, South Solok, and West Pasaman regencies is still not optimal in increasing the regional PAD. Regional financial performance is one measure that can be used to see the ability of the regions to carry out regional autonomy. [1] An opinion that the form or output of regional financial performance appraisal is in the form of financial ratios formed from the elements of the regional head's accountability report in the form of APBD calculations.

Therefore, it is necessary to research the level of independence and regional financial performance in post-division Regency in West Sumatra Province in supporting regional financial independence in the era of fiscal decentralization and providing information to the public regarding the presentation of financial report data and financial performance of local governments in this Regency.

Research on this topic is very important to do to contribute ideas to related parties to optimize regional financial performance, especially in the field of financial independence and the level of dependence of regional finances on central finances, both provincial and central government through balancing funds. In this study, it is hoped that each region will be able to independently manage regional finances through its regional revenue (PAD). The results of this study are expected to be input in policymaking for superiors, by looking at the important factors that affect regional financial performance, especially on the level of regional financial independence and from the results of this study can also provide suggestions, steps that must be taken to optimize financial performance. the future area.

\section{Methodology}

The research method used a quantitative descriptive approach. Descriptive type because this research seeks to reveal and understand the phenomena that occur, which in turn provides a clearer understanding and information about the phenomenon under study. Meanwhile, the use of quantitative methods is due to the approach used in the research proposal, the process, the hypothesis, the analysis of the data, and the conclusion of the data until writing using aspects of measurement, calculation, formulas, and certainty of numerical data [7]. The research sample used a purposive sampling technique. The research was conducted in three Regency after the division of West Sumatra Province, Dharmasraya, South Solok, and West Pasaman Regency. Data collection techniques through observation and documentation/literature study. The data used is secondary data, namely the regional budget realization report (LRA) after the expansion of the 2014-2018 period starting from the last five years. The data used are data relating to the growth of local revenue and the contribution of PAD sources to total PAD and regional financial performance, through financial ratio analysis. Includes, degree of decentralization, financial dependency ratio, and financial independence ratio. 


\section{Finding And Discussion}

\subsection{Local Own Revenue Growth}

The analysis of the growth in local revenue is useful for knowing whether during the 20142018 fiscal year the growth of PAD in Dharmasraya, South Solok, and West Pasaman Regency experienced positive or negative growth. Of course, the hope is that PAD growth must be positive and there is an increasing trend in each fiscal year. According to the opinion of [8], The growth ratio is useful for knowing whether the local government in the fiscal year of supervision or during several budget periods, has experienced positive or negative growth in revenue or expenditure. To see the trend of PAD growth in Dharmasraya, South Solok, and West Pasaman Regency from the 2014 to 2018 fiscal year period can be seen in Figure 1 below:

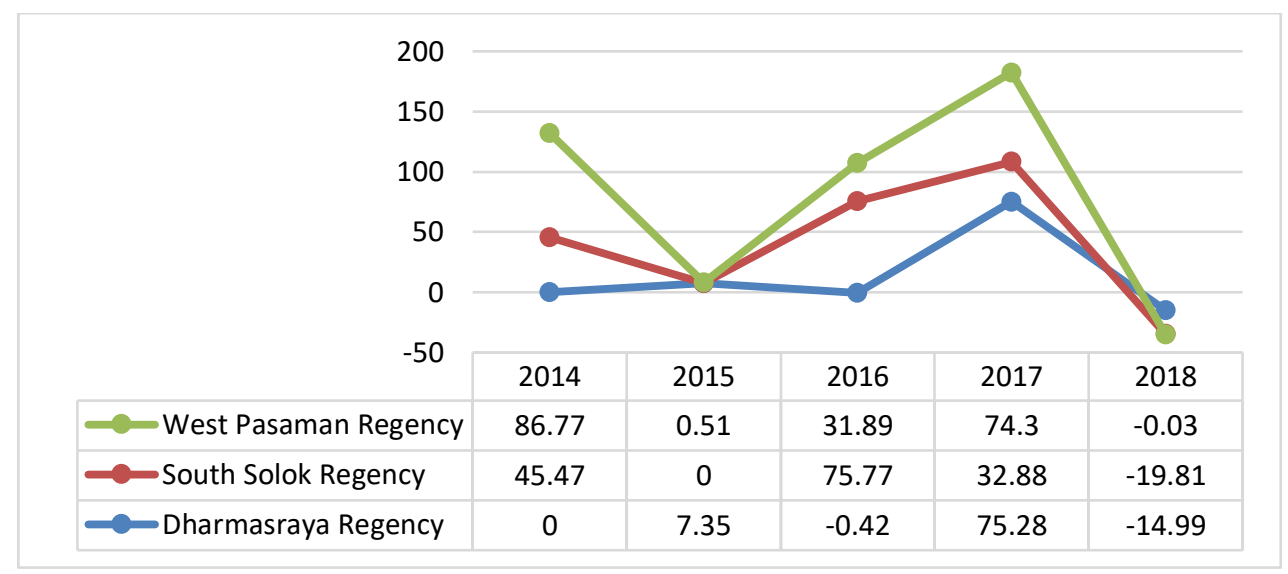

Figure 2. Growth Ratio of PAD

During the observation period, the PAD of Dharmasraya, South Solok, and West Pasaman Regency experienced an average growth of $26.33 \%$. The average growth of PAD in the Dharmasraya Regency is $13.44 \%$, PAD Solok Selatan is $26.86 \%$, and PAD Pasaman Barat is $38.69 \%$. The largest average growth came from West Pasaman and the smallest average growth came from Dharmasraya Regency. This data shows that the average growth rate of the growth ratio of PAD in the Regency of Dharmasraya, South Solok, and West Pasaman experienced fluctuating growth, whereas the growth of PAD in Dharmasraya Regency was still inadequate because it was still below the average growth rate of PAD as a whole for the three post-division Regency in West Sumatra Province. So from this data, it is necessary to find the cause of the decline in PAD in each region to increase its growth in the coming period. Meanwhile, for the average growth of PAD during the 2014-2018 fiscal year, South Solok and West Pasaman Regency show that the growth of these two regional PAD sources is already above the average PAD growth ratio. However, the PAD of these two regions will continue to be optimized in the coming periods, especially to increase regional financial independence.

\subsection{Contribution of Local Revenue Sources}

The contribution referred to here is the amount of contribution that PAD sources can make to the amount of PAD seen as a percentage of each fiscal year. The size of the contribution can 
also reflect the magnitude of the role of each of these PAD sources. For a clearer picture of the contribution of the PAD sources, please see table 1 below.

Table 1. Average Contribution of PAD Sources to Total PAD in Dharmasraya, South Solok, and West Pasaman Regency 2014-2018 (in Percent)

\begin{tabular}{lcccc}
\hline $\begin{array}{l}\text { Sources of Local } \\
\text { Revenue }\end{array}$ & Local Tax & $\begin{array}{c}\text { Regional } \\
\text { Retribution }\end{array}$ & $\begin{array}{c}\text { The Result of } \\
\text { Separated } \\
\text { Regional } \\
\text { Wealth } \\
\text { Management }\end{array}$ & $\begin{array}{c}\text { Other } \\
\text { Legitimate } \\
\text { Original } \\
\text { Regional } \\
\text { Income }\end{array}$ \\
\hline $\begin{array}{l}\text { Dharmasraya } \\
\text { Regency }\end{array}$ & $10,87 \%$ & $2,26 \%$ & $3,00 \%$ & $82,87 \%$ \\
$\begin{array}{l}\text { South Solok } \\
\text { Regency }\end{array}$ & $7,85 \%$ & $8,84 \%$ & $2,45 \%$ & $80,87 \%$ \\
$\begin{array}{l}\text { West Pasaman } \\
\text { Regency }\end{array}$ & $11,90 \%$ & $8,88 \%$ & $1,45 \%$ & $77,78 \%$ \\
Rata-rata & $\mathbf{1 0 , 2 1 \%}$ & $\mathbf{6 , 6 6 \%}$ & $\mathbf{2 , 3 0 \%}$ & $\mathbf{8 0 , 5 1 \%}$ \\
\hline
\end{tabular}

Based on table 1 above, it can be concluded that for Dharmasraya, South Solok, and West Pasaman Regency, the PAD elements that made the largest contribution to total PAD since the 2012-2016 fiscal year were sourced from other legal PAD with a large contribution in percent of $80,51 \%$ is then followed by local taxes of $10.21 \%$, the third place is regional levies of $6.66 \%$ and the smallest is the result of regional wealth management which is separated by an average contribution of $2.30 \%$. In general, other legitimate PAD contributions are the biggest contributors to revenue in Dharmasraya, South Solok, and West Pasaman Regencies.

\subsection{Regional Financial Performance Analysis}

The analysis of financial performance in the Regional Budget (APBD) is carried out by comparing the results achieved from one period compared to the previous period so that it can be seen how the trend occurred [9]. Besides, it can be done by comparing the financial ratios of a particular regional government with the financial ratios of other nearby regions or relatively the same regional potential to see how the financial position of the local government is relative to other local governments. Financial ratio analysis is a process that identifies important features of the company's financial condition and activities based on available financial reports.

To be able to find out the financial performance capability of Dharmasraya, South Solok, and West Pasaman Regency in implementing regional autonomy and fiscal decentralization, especially in increasing regional financial independence, it can be done using financial ratio analysis as follows:

\section{1) Degree of Decentralization}

The degree of decentralization is calculated based on the ratio between the total local revenue and the total regional revenue. This ratio is intended to measure the level of equity in the distribution of regional resources in the form of revenue sharing according to regional potential 
to total regional revenues. This ratio also shows the degree of PAD contribution to total regional revenue. The higher the PAD contribution, the higher the capacity of the regional government in administering decentralization. PAD is an aspect that determines the success of a region in implementing decentralization. The higher the PAD, the greater the regional financial capacity to finance government spending in running the wheels of government.

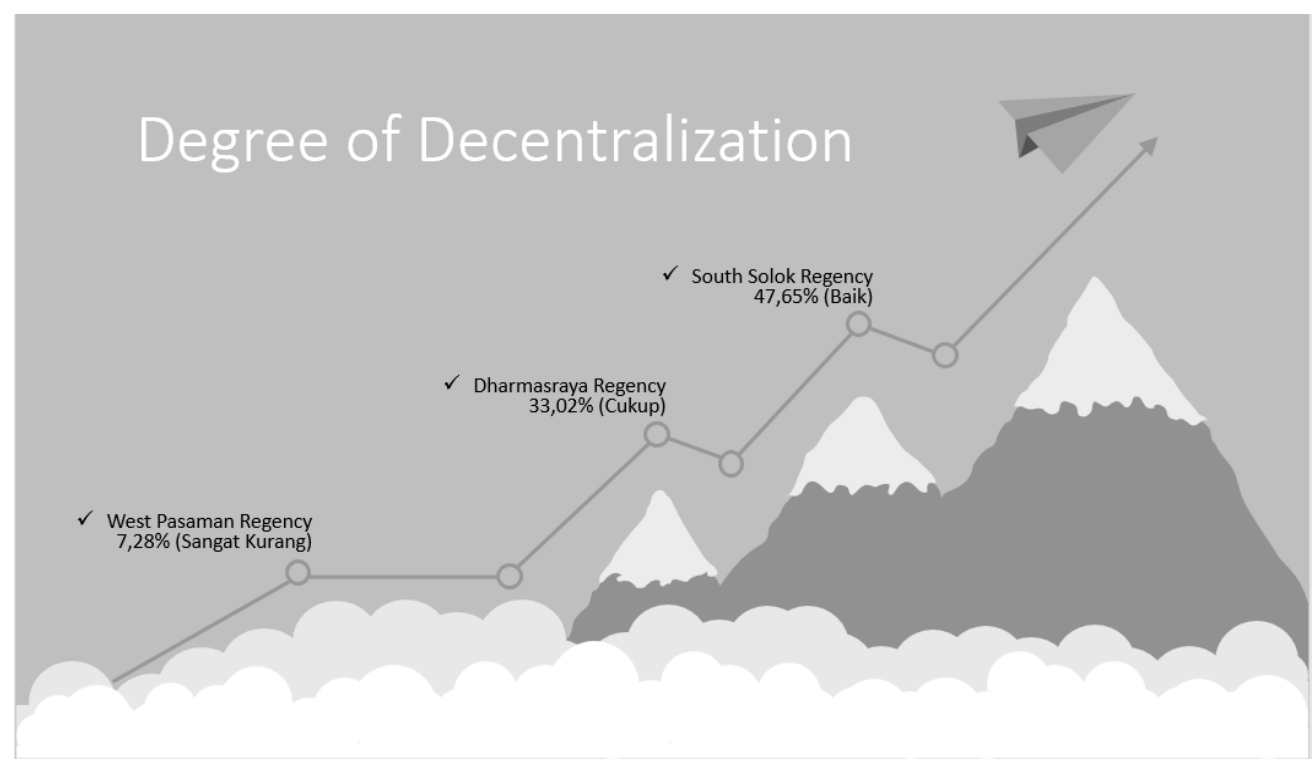

Fig.3. Derjad's Level of Decentralization

From Figure 2 above, it can be ignored that the degree of fiscal decentralization in the Dharmasraya Regency is in the moderate degree of decentralization, South Solok Regency is in the good category of decentralization, while West Pasaman Regency is in the very poor category of decentralization. Meanwhile, if viewed as a whole, the level of fiscal decentralization in the post-division regions in West Sumatra Province is in the "medium" category of decentralization with the acquisition of a percentage value of $29.50 \%$. South Solok Regency is the Regency with the best decentralization degree in this period, namely in the good category with a value of $47.65 \%$ above the overall average, while for Dharmasraya Regency it is in the sufficient category but the average value is above the average value. whole. Meanwhile, the degree of decentralization in the West Pasaman Regency is at the lowest level with a value of $7.28 \%$ being in the very poor category.

\section{2) Regional Financial Dependency Ratio}

The regional financial dependency ratio is one of the dimensions used to measure the financial performance of a region. The financial dependency ratio is obtained by comparing transfer income with total regional income. The assumption is that when the percentage ratio of regional financial dependence is higher, the impact on the level of regional dependency will also be greater and vice versa, when regional financial dependence is lower, the level of regional dependency will be smaller. Dependency in question is the dependence of regions on financial distribution from the central government and / or on the provincial government in terms of financing both for financing development and for financing services. 
To see the financial dependency ratio in Dharmasraya, South Solok, and West Pasaman Regency in the 2014-2018 period it can be concluded that the three regions for dependency ratio are at a very high level, namely $\geq 50.01 \%$, both the Regency of Dharmasraya, South Solok, and West Pasaman. This can be seen because in general, regional income funds through transfer funds from both the central government and the provincial government are still quite high when compared to the total regional revenue funds.

\section{3) Regional Financial Independence Ratio}

The ability of regions to produce PAD is one of the most important aspects related to regional financial independence, where the ability of the regions to autonomously manage and explore PAD resources so that they can increase regional finances which will later be used by regional governments to finance development, government administration and improve quality of service to the community.

To determine the ability of a region to generate PAD, the self-reliance ratio is used, which is obtained from the comparison between the original regional income divided by several sources of funds for financing in the region, such as the number of transfer funds from the central government, from the provincial government and the nominal amount of regional loans. Both revenues from transfers (central government and provincial governments) and regional loans are calculated together so that one macro calculation is obtained. The magnitude of this macro calculation will then be used as a comparison of the amount of local revenue, the result is only the ratio of regional independence.

Conceptually, the pattern of relations between the central government and regional governments must be carried out by the regional financial capacity to finance the implementation of governance and development. Paul Hersey dan Kenneth Blanchard [10] [11] introducing four kinds of situational relationship patterns that can be used in the implementation of regional autonomy, namely:

a) Instructive Relationship Pattern, the role of the central government is more dominant than the independence of the local government. (Regions that are unable to carry out regional autonomy);

b) The pattern of Consultative Relations, the intervention of the central government has begun to decrease because the regions are considered to be slightly more capable of implementing regional autonomy;

c) Participatory Relationship Pattern, the role of the central government is decreasing, given that the region concerned has a level of independence that is close to being able to carry out autonomous affairs.

d) Delegative Relationship Pattern, central government interference is not there because the regions are truly capable and independent in carrying out regional autonomy affairs.

From the calculation of the ratio of regional financial independence for Dharmasraya, South Solok, and West Pasaman Regencies in the 2014-2018 period, it can be concluded that the three regions for the self-reliance ratio are at the low category or Consultative level. The pattern of Consultative Relations, namely the intervention of the central government has begun to decrease because the regions are considered to be slightly more capable of implementing regional autonomy. This achievement is inseparable from the financial situation in the Regency of Dharmasraya, South Solok, and West Pasaman which still mostly rely on balancing funds from both the province and the center through central and provincial transfers. Even in the 2014 fiscal year and 2018 fiscal year, almost all regional revenue came entirely from central and provincial 
transfer funds. This situation has made regional autonomy in terms of financial independence still difficult to achieve in the Regency of Dharmasraya, South Solok, and West Pasaman.

\section{Conclusion}

The growth trend of PAD in the Regency of Dharmasraya, South Solok, and West Pasaman during the last five years, namely 2014-2018, has experienced an average growth of $26.33 \%$. Wherefrom PAD sources that greatly contributed to the total PAD came from Other legitimate PAD with an average contribution of $80.51 \%$. The growth trend of PAD in the Regency of Dharmasraya, South Solok, and West Pasaman during this period on average had a positive projection (positive trend) except that in 2018 the trend of PAD growth led to a negative growth trend for the three regions. The contribution of original regional revenue to regional revenues in the last five years was still very small, still below 50\% from year to year. The financial performance of the Dharmasraya, South Solok and West Pasaman regencies is low based on financial ratios. Where the ratio of the degree of decentralization is in the medium category, namely $29.50 \%$. The ratio of regional financial dependence is very high with an average value still above $\geq 50.01 \%$, the ratio of regional financial independence is low or shows a pattern of consultative relationships.

From the results of this study, it is suggested that the Regency governments of Dharmasraya, South Solok, and West Pasaman continue to improve regional financial independence and reduce the level of dependence on the central and provincial governments. In accordance with the results of the identification of existing regional original revenue potential, it can be done by optimizing the increase through the results of separated regional wealth management, regional levies, and local taxes.

Acknowledgment The authors would like to thank the Institute for Research and Community Service (LP2M) Padang State University for funding assistance for PNBP research for the fiscal year 2020 based on Decree Number 1824UN35 / LT / 2020 and Contract Agreement Number 1275 / UN35.13 / LT Year 2020, the author is also would like to thank the Regency Governments of Dharmasraya, South Solok, and West Pasaman, in this case, the Regional Financial Management Agency (BPKD) of Dharmasraya, South Solok, and West Pasaman Regencies for being the places for this research and thanks to the research team, so that this research can be completed on time.

\section{References:}

[1] E. Koswara, "Menyongsong Pelaksanaan Otonomi Daerah Berdasarkan UndangUndang Nomor 22 Tahun 1999: Suatu Telaahan dan Menyangkut Kebijakan, Pelaksanaan dan Kompleksitasnya," Anal. CSIS XXIX, vol. 1, 2000.

[2] A. Halim, Manajemen Keuangan Sektor Publik. (Problematika Penerimaan dan Pengeluaran Pemerintah). Jakarta: Salemba Empat, 2014.

[3] R. Indonesia, UU Nomor 33 Tahun 2004. 2004. 
[4] M. of the Interior, Minister of Home Affairs Regulation No. 13 of 2006 concerning Guidelines for Regional Financial Management. 2006.

[5] I. T. Ritonga, Analisis Laporan Keuangan. Yogyakarta: Pustaka Pelajar, 2014.

[6] B. Saputra and R. Fernando, "Kontribusi Sumber-Sumber PAD Dalam Mendukung Kemandirian Keuangan Daerah di Kabupaten Sleman," J. Ris. Akunt. dan Keuang. Progr. Stud. Akunt. Fak. Pendidik. Ekon. dan Bisnis Univ. Pendidik. Indones., 2017.

[7] Sugiyono, "Metode Penelitian Kuantitatif, Kualitatif dan Kombinasi (Mixed Methods)," Bandung Alf., 2016.

[8] Mahmudi, Manajemen Kinerja Sektor Publik. Yogyakarta: UPP STIM YKPN, 2010.

[9] A. Halim, Akuntansi Sektor Publik Akuntansi Keuangan Daerah. Jakarta: Salemba Empat, 2004.

[10] D. D. A. A Helfert, Erich, Analisis Laporan Keuangan. Edisi Ketujuh. Jakarta: Erlangga, 2000.

[11] A. Halim, Bunga Rampai Manajemen Keuangan Daerah. Edisi Revisi. Yogyakarta: AMP YKPN, 2004. 